\title{
Language as Project Activity
}

\author{
Tatiana V. Tarasenko* \\ Reshetnev Siberian State Aerospace University \\ 31 Krasnoyarsky Rabochy, Krasnoyarsk, 660037, Russia
}

Received 16.09.2015, received in revised form 29.09.2015, accepted 20.10.2015

This article is about the language that is the object of campaigns and projects. These events (the Total Dictation and Dicos d'or) firstly attract the attention of the media, and due to them the civilian population shows the interest for the campaign. Such pseudo-events as "The millionth English word" provoke a scientific discussion about the lexical richness of a language, attract the general public and stimulate interest in the language, in studying it.

Keywords: campaign, media, language, civilian population.

DOI: 10.17516/1997-1370-2015-8-11-2669-2676.

Research area: pedagogy, philology.

\section{Introduction}

The language is mostly studied as an object of linguistics in a particular perspective, namely functional, pragmatic, semantic, etc. We would like to consider the language as a project or campaign that attracts the attention of the media, thus, in our view, stimulates an interest in the language, in studying it.

\section{The total dictation (Russia)}

To begin with, we will consider a successful project of civil society in Russia - a Total Dictation. The total dictation is an annual educational event designed to attract attention to the issues of literacy and develop a culture of competent writing. The point of the event is to make a voluntary free dictation for everyone. The Total Dictation is a type of flash mob. Unfamiliar people know about the campaign in the Internet, gather in one time at one place, do something strange together and break up. Before erudition and literate writing were associated with the concept of "elite" and "respect". With time consumer culture changed the guidelines, so the level of culture and, particularly literacy became the images of "a loser" and "tedium" showing how youth represents boredom and the notorious form of dictation. According to the organizers, the Total Dictation is designed to destroy this stereotype and make literacy fashionable.

We will refer to the history of the project. The first Total Dictation was performed out on 11 March, 2004 at Novosibirsk State University. The initiators of the dictation were the participants of the student club "Glum club". Within five years, it was an annual event, gathering about 200 participants, with no differences from school campaigns. In 2009 Psoy Korolenko -

(C) Siberian Federal University. All rights reserved

* Corresponding author E-mail address: tvt2004@mail.ru 
a philologist, a member of performances and show "Minute of Fame" on Russian television, a bard who lives in the United States, performing songs with frivolous content, was invited to participate in the dictation. That is how the dictation changed its format and became sort of a show. That time 600 people came to write it.

In 2010 the Total Dictation gathered 2400 participants. Other Novosibirsk universities, schools and libraries joined Novosibirsk State University, and the dictation was held at 17 locations across the city. The ministers of the regional government, prominent scientists and businesspeople took part in writing the dictation. Local celebrities, TV and radio hosts and honoured teacher read the dictation text to the participants. The writer Boris Strugatsky wrote the text of the dictation specifically for the event. The vast majority of local media and several federal media reported the event.

In 2011 another total dictation took place in 13 cities of Russia and Boston (USA). 4700 people attended the event; another 500 watched the online broadcast. The author of the total dictation 2010 text was a writer Dmitry Bykov.

In February 2011 the Total Dictation 2010 won the National Award in the field of Public Relations "Serebryani luchnik" as the best Russian public project.

64 thousand people wrote the Total Dictation 2014 in 342 cities (5750 of them were abroad), including the astronauts of the International Space Station (ISS). People wrote it in Vladivostok and Kaliningrad, Moscow and St. Petersburg, Novosibirsk and Krasnodar, Kharkov and Kiev, Naryan-Mar and Polar Zori, Marrakesh, Singapore, Boston, Rome, Guangzhou, Prague, Paris, Amsterdam and in dozens of other cities in Russia and the world. There are reports and photos from Antarctica, where five employees of Russian polar stations wrote the Total Dictation. In Moscow, the dictation text was read by Konstantin Khabenskii and Maksim Krongauz, and in Paris - by director Kira Muratova (totaldict.ru).

In 2014 the Total Dictation was widely covered by "Russian reporter" magazine in the context of "Russian-language 24" project. It was one day in the life of Russian-speaking people in more than 100 cities in Russia and the world, who came to write the Total Dictation on 12 April.

The main objective of the project "Russian language-24" as part of the Total Dictation was to demonstrate the role played by the Russian language in the life of Russian-speaking people throughout the world.

On April 12, 2014, dozens of reporters and photographers around the world were broadcasting the event. In their notes, they described who and how organized the campaign, who and why came to write the dictation. They talked to famous people reading the dictation text, spent the day with the author of the text - a well-known modern Russian writer Alexei Ivanov. All the journalists were interested in all the details of the process, so the reporters broadcasted everything that happened at the Total Dictation - before, after, and during it (more on the link http://24.rusrep. ru/dossier/pub_point/russkij-yazyik- 24 /? tags = $37962 \&$ page $=$ ).

On April 12, 2014, 00:00 o'clock Moscow time, on the website 24.rusrep.ru the notes of the participants of the event were online. The motto of the action was "Russian language -24" - write the Total Dictation with the world!

The literary observer K. Milchin from "Russian reporter" was one of the readers of the text: "I was asked: "Do you want to read in Kaliningrad "the Total Dictation"? "I said: "I want." If I had to read it in Norilsk, Makhachkala, Noyabriskiy's village, Okhotsk, tundra, taiga, desert or anywhere in the Kuril Islands, I would have gladly accepted” (Russian reporter. №16-17. April 24 - May 15, 2014). 


\section{«Golden Dictionary» (France)}

It should be noted that the Russian Total Dictation is referred to another wellknown projects - "The French Orthography Championship." From 1984 to 2005 France conducted a national competition called (from October 4, 1993) «Dicos d'or» («Golden Dictionary»). The ideological mastermind of the project was lexicographer Micheline Somman and the publisher of "Lear" magazine Jean-Francois Druar, its chief editor Pierre Bonsen and Bernard Pivot. The sponsor of the championship was the bank "Credit Lyonnais"; since 1993 the regional semi-finals have been broadcasted on television channel France 3. The winners were awarded the prize "Golden Dictionary" and for those who took the next places - silver and bronze dictionaries. The texts of dictations were made by Somman Micheline (for the semi-finals) and Bernard Pivot (for the finals).

The championships were held in three stages:

1. Qualifying round: a questionnaire with multiple-choice questions and the text, where it was necessary to correct mistakes. The literary magazine "Lear" published the material on its pages.

2. Regional semi-finals: candidates, who passed the qualifying round, were invited to the regional competitions, whose spot was changed every year. The test task included a questionnaire with multiplechoice questions, the actual dictation, and mini-dictation.

3. National Finals: the candidates, who showed the best results in each of the categories of participants in the region, all gathered in one place to take part in the winter final. The final was held on the same formula as semi-finals.

The competitions were held separately for the four categories of participants: 1) junior- school children; 2) juniors; 3) adult amateurs; 4) adult professionals.

Began as a national championship, the competition very quickly attracted foreign participants. The culmination was the dictation, held in 1992 at the UN headquarters in New York. About 250 contestants from all over the world attended it to compete for the world title.

After this event, the organizers of the competition brought it back to its national status. With time, dictations were widened with a multiple-choice questionnaire for understanding the meanings of words. Internationally Dictation resumed in 1994 in the America.

«Dicos d'or» became the most significant event of the French language, which was annually attended by about 550000 students and more than 10000 adult orthography admirers.

But how explain such a remarkable zeal with which French-speaking audience regularly takes part in the championship? Here are some of Bernard Pivot' thoughts: «Dicos d'or» owes its success to the spirit of competition that occurs in the family. Who will make fewer mistakes? The grandparents, parents or children? And it happens that adults with wonder and admiration discover that the young generation surpasses them in unexpected ways in possession of native speech".

Another factor to the success of the championship was the diversity of the social status of participants, which strengthened the state channels management's confidence to broadcast the event for the public importance.

Housewives competed with programmers, professors and students, townspeople mingled with countrymen, ordinary employees and unemployed peacefully were sitting side by managers, pensioners were happy to be among young people.

"The dictation is a sport accessible to everyone ..., moreover, the event is purely 
voluntary, and it is not very serious. It is more like a game in which all players play with words. Champions get books as a reward, and the losers - a warm farewell speech and gratitude for their love to the French language. And it's quite a lot!".

«Dicos d'or» life on the channel France 3 ended November 26, 2005, with super final, which brought together the champions of previous years. It was B. Pivot's airing as the TV host. He created the contest 19 years ago..

In 2000 Bernard Pivot opened dicosdor. com site dedicated to the French language and spelling in memory of the French championships on spelling «Dicos d'or». The championships had been performed since 1985, and since 1993 had been broadcasted on television channel France 3.

This site, addressed to philology lovers and 181 million native French, is a "continuation of the TV channel France 3, which gathered up to 2 million viewers during the regional semi-finals and national finals."

The site presents itself as "an educational portal dedicated to the French language" and offers visitors old dictations catalogue, online dictations, spelling tests and a variety of games with words. As well as the "word of the day" by Jean-Pierre Collignon and the "question of the day" or a "ticket of the day" by Bernard Pivot. Here you can find books and reference books for the teaching and learning the French language and, of course, Bernard Pivot's dictations.

B. Pivot published a series of books «Dicos d'or». In 2004, the book "100 mots à sauver» («100 words that have to be saved") was published. The book contained the words that, according to the author, were obsolete. We do not use them anymore. The journalist gives each word a comment and description. M.A Krongauz called B. Pivot a "words rescuer" [Krongauz 2007: 100].

\section{«The millionth English word» (USA)}

Another project resounded through the whole world was the campaign "a millionth English word". In 2003 the marketing expert and analyst Paul J.J. Payack founded in Silicon Valley company GLM (Global Language Monitor, site www.languagemonitor.com) and since 2006 had repeatedly stated that soon a millionth English word would be recorded. February 12, 2006, Internet website newsru.com reported that «experts expect the forthcoming of a millionth word in the English language» (http://www. newsru.com/world/12feb2006/yas.html).

From one of the notes: «Due to the wide prevalence of the English language on the planet, it is enriched with new words every day. According to some estimates, every 98 minutes, a new English word comes into the world. Experts consider the word new if the frequency of its use in newspaper articles, Internet, and other sources is more than 25 thousand times.

Global Language Monitor Academic Association, which works on studying and including new words to the dictionaries, suggested that at 10:22 June 10, 2009, a jubilee millionth English word would come into the world. Terms claim to be a millionth word most often associated with the Internet or environmental themes. For example, one of the candidates is an internet term «defriend» which means means to remove the user from your friends list in a blog or social network. Another candidate is «greenwash» which means attempts by various companies to seem more friendly to the environment than they actually are. One more word from the Internet is «noob». The word originates from online games and means a beginner, newbie» (http://pro-lingua. ru/millionthnoe-slovo-v-angliyskom-yazike/).

On June 11, 2009, The Times wrote the following: A millionth word came into the English language, writes The Times referring 
to the website, following the appearance of new words, - Global Language Monitor.

"Millionth word is a milestone that indicates the onset of the era of English as the first truly global language," - said Paul J.J. Payack, president and chief analyst at Global Language Monitor.

In contrast to the Oxford English Dictionary, which includes only English words and phrases, Global Language Monitor considers the hybrid word from Chinese English, Spanish English, terms from the film industry, computer slang and words from the Internet, writes Ben McIntyre.

A millionth term that widened the English language was the expression "Web 2.0," which is used to refer to a new generation of web-based products and services.

Three other terms fighting for the title, but lost to "Web 2.0" were:

- a Spanish-English expression "Jai Ho!" signifying a major achievement;

- The word "Slumdog" which became popular thanks to the film "Slumdog Millionaire". It means "a child, living in the slums";

- A mixture of letters and numbers "n00b" invented to mock on a newcomer to the game community on the Internet (http://www.inopressa. ru/article/11Jun2009/times/word.html).

If we consider "a million English word" campaign as concerning marketing and selfpromotion of Global Language Monitor, it was successful and broadly covered by leading world's media. But unlike two previous projects discussed above, this event has given a way to many questions and complaints, scientific disputes, discussions, and insults. For example, one of the visitors of Translation bureau "Norma TM" wrote: "It is well known that the vocabulary of different languages varies. Civilized man's vocabulary may be ten times higher than the vocabulary of a representative of the savage tribe in Africa. It is also understood that people from different social levels have different vocabulary - you can't compare the child and the adult, the street cleaner and the professor. In any case, no one doubts that a more extensive vocabulary is always linked to the knowledge and intellectual superiority. Now, what would you think if someone officially declared that our Russian language is savage and contains five times fewer words than English? You for sure would challenge this nonsense! However, such a "scientific view" was repeatedly broadcasted in the media. It cannot but cause concern." The aims of such campaigns he saw as follows: "I cannot help thinking that some of these statements are paid-for and have a suggestive purpose. Someone needs the territory of the country to be a source of cheap raw materials with humble and small population, deprived of national identity and pride. In this context, I understand the stroke on the Russian language as the basis of culture and self-identity. The main thing is not to "be taken in" (here is another neologism, by the way)" (http:// www.norma-tm.ru/psychological_war.html).

The first claim, which is expressed by lexicographers and linguists and experts in English, is simple: what is the counting method of the new words? Here are some opinions.

The newspaper "New York Times" wrote about the millionth English words: "Language experts, when they were asked to comment on this fact, were very critical making estimates, used some unprintable words.

"This is nonsense, fraud and rubbish," - said linguist Geoffrey Nunberg from the School of Information at UC Berkeley.

"It is a lie, a swindle and a fake. It is not true, "- lexicographer and co-founder of online dictionaries Wordnik.com Grant Barrett said.

"Our fascination with the immensity of the English language, - said Mr. Nunberg comes from sort of linguistic imperialism - the feeling that" our dictionaries are greater than their dictionaries. "But in fact, it does not make 
us linguistically richer", - he said (http://www. sovross.ru/modules.php?name $=$ News $\&$ file $=$ articl e\&sid=596493).

January 32009 American linguist and lexicographer Ben Zimmer underlined that "gullible reporters keep plunging in self-exalting fraud committed by Paul J.J. Payack controlling GLM». He also pointed that the method of counting the words is unknown; that there are periods of stagnation coinciding with Payack's books publication, and it is reflected in the time of coming of new English words.

One of the visitors to the Translation bureau "Norma TM" suggested "include all Chernomyrdin's mistakes in the dictionary and thereby "surpass America"!". Here is his comment: "Analysis of Global Language Monitor consists of several stages. On the first stage, the words that were included in the famous English Dictionary such as Merriam-Webster's, Oxford English Dictionary, Macquarie's were counted. It is worth noting that the latest edition of Merriam-Webster's dictionary includes only 450,000 English words. On the second stage, the company's employees take into account all English neologisms using a special algorithm. At the same time, the Internet texts including blogs and other informal network resources are analysed. The periodicals both in electronic and paper form, new items of various literatures are taken into account. This particular technique triggers a barrage of criticism from independent experts toward Global Language Monitor Company. The main reproach is that the counting includes both obsolete words and phrases as well as slang formations. Moreover, the Company takes into account the words that are used only in the varieties of English, for example, in China and Japan. This makes nearly $20 \%$ of the total number of words that specialists approve. Furthermore, the language mistakes made by the President of the United States - G.
Bush were counted as lexical innovations of the English language» (http://www.norma-tm.ru/ psychological_war.html).

Another complaint against the campaign organizers was a linguistic problem - what can be considered a word?

The editors from the publishing company Merriam-Webster share their opinions in the article "How many words are there in the English language?". They write: "It is believed that English Dictionary contains about 1 million words (though most linguists would have taken such an assessment with a bit of humour and some said they would not be surprised if it was estimated at a quarter of a million). This counting includes the names of countless chemicals and other scientific objects. Many of them are so peripheral for general use in English, so some of them are absent from, or they are unlikely to appear even in the unabridged dictionary (http: // www. Merriam-webster.com/help/fag/total_ words.htm).

The campaign "millionth English word" has become a catalyst for scientific discussion about the lexical richness of languages, including Russian.

An American professor of cultural theory and Russian Literature at Emory University, M. Epstein in an interview to "Rossiyskaya Gazeta" said "I have no words... In our lexicon there are seven times fewer words than in the English language". He argues that the English language during the twentieth century has increased its vocabulary up to 750 thousand words. At the same time, the Russian language has met looses and it has no more than 150 thousand lexical units. "That's why you need to sound the alarm: how far the Russian language in its present state allows to make a though necessary for full inclusion in the noosphere of the XXI century, for conceptual influence on the minds and informative interaction with 
other languages." But for all that this interview appeared before publication of Epstein's book "Iazykovodstvo" in which he offers new words for love's vocabulary as successful, such as liu'b, liublia, bezliub'e, neliub', ravnoliub'e (http:// www.rg.ru/2006/07/25/a118006.html).

Another participant in the scientific discussion was a leading researcher of Dictionaries Department of the Institute of Linguistic Studies of RAS, Ph.D., L.E. Kruglikova. In her works, she answered to questions from an American professor [Kruglikova 2014: 158-159].

In her work "Ne mudrstvuite lukavo" she fairly writes: "About the pompous phrase of M.N. Epstein "And in fact, you can compare: 750 thousand and 150 thousand", the answer can be the following: "and, in fact, is it possible to compare the approximately 600 thousand modern Russian words and more than 600 thousand English words. And the history of its development is more than thousand year"?! ... The following can be said about the English language: approximately 190 thousand words of modern English is disappointingly little for the language, which claims to be the global language, which is native to the vast majority of the population, imagining themselves as super state, aspires to influence the fate of humanity; and the language that is native to nearly 410 million people, billion people have this language as the second language"(Soviet Russia. 03.04.2014).

\section{Conclusion}

I would like to complete this study with the words of K. Milchin whose opinion was already cited above: "The things I am going to say now may sound posh, but it is really true. Somehow, the main wealth of our country is mistakenly believed to be oil, gas and khaki shooting pieces of iron. But in fact, our main wealth is the Russian language. And it is not great and mighty, it is simply very beautiful. A well-written text on the proper Russian can bring a real pleasure if you cultivate a taste for a good language. That is why we need such great campaigns as the "Total dictation" (Russian reporter, No.16-17. April 24 May 15, 2014).

\section{References}

Krongauz M.A. Russkii iazyk na grani nervnogo sryva [Russian language is on the verge of a nervous breakdown]. Moscow, Symbol, Languages of Slavic Cultures, 2007. 232 p.

Kruglikova L.E. Dostatochno li v russkom iazyke slov dlia vyrazheniia myslei? [Is there enough words to express thoughts in Russian?]. Russkii iazyk: istoricheskiie sud'by i sovremennost' [Russian language: historical destiny and modernity: International Congress of Russian researchers (Moscow, Lomonosov Moscow State University, Faculty of Philology, March 18-21, 2014): Works and materials. Compiled by M.L. Remneva, A, A. Polikarpov, O.V. Kukushkin. Moscow, Lomonosov Moscow State University, 2014. 848p. 


\section{Язык как проект}

Т.В. Тарасенко

Сибирский государственный аэрокосмический университет имени академика М.Ф. Решетнева Россия, 660037, Красноярск, пр. Красноярский рабочий, 31

В статье речь идет об акииях и проектах, объектом которых является язык. Это мероприятия-шоу (Тотальный диктант и Dicos д’op), которые вначале привлекают внимание медиа, а через них интерес к акииям проявляет и гражданское население. Это псевдонаучные акции типа «Миллионное слово английского языка», которые провоцируют научную дискуссию о лексическом богатстве того или иного языка, привлекая к ней широкую публику и стимулируя интерес к языку, к его изучению.

Ключевые слова: акиия, медиа, язык, гражданское население.

Научная специальность: 13.00.00 - педагогические науки, 10.00.00 - филологические науки. 